\title{
STUDY ON THE HYDROLYSIS PROCESS OF FOOD AND FEED SAMPLES USING HIGH PRESSURE ASHER (HPA-S) TO DETERMINE SEVERAL AMINO ACIDS BY HIGH PERFORMANCE LIQUID CHROMATOGRAPHY
}

Dinh Viet Chien*, Nguyen Tien Luyen, Nguyen Thi Hong Ngoc, Pham Cong Hieu, Do Tat Thanh, Pham Thu Giang, To Quoc Tuong, Nguyen Thi Lan, Duong Minh Tuan, Doan Van Kien

National Institute for Food Control (NIFC)

(Received on: 15/4/2019; Revised on: 20/5/2019; Accepted: 27/5/2019)

\section{Abstract}

The study researchs on the hydrolysis process of food and feed samples using High Pressure Asher (HPA-S) to determine several amino acids by high-performance liquid chromatography (HPLC). HPA-S equipment is mainly used for samples treatment in analysis of metals by spectroscopy. However, the study also found that HPA-S can be used in hydrolysis of food and feed samples in order to analyze amino acids. The temperature of HPA-S equipment could reach $300^{\circ} \mathrm{C}$ and maintain continuously at 130 bar pressure, completely digetsing the most complex samples matrix within an hour. The successful study of the application of HPA-S to hydrolyze samples in order to analyze amino acids makes the time of sample preparation significantly shorter but still gave the equivalent stability, even higher than the common samples hydrolyzation.

Keywords: food, feeding, amino acids, HPA-S, hydrolysis, HPLC.

\section{INTRODUCTION}

The determination of amino acids mainly used derivatization method with some specific reagents and then could be analyzed by high-performance liquid chromatography with fluorescence detector. In most cases, the steps of sample preparation are complicated, taking so much time to make the hydrolysis of samples in a closed system using an oven or reflux heater (from 18 to 24 hours). Therefore, it is necessary to develop a simpler sample treatment method, shortening the sample hydrolysis time and achieving the same results.

In this study, the system of High pressure asher (HPA-S) specifically for samples digestion to analyze metal elements was used for the purpose of hydrolyzing amino acids in food and feeding samples. Then, amico acids were determined by high-performance liquid chromatography (HPLC). The research objective is to shorten the time of sample preparation but it still ensures the stability and effectiveness of the hydrolysis process.

\section{SUBJECTS AND RESEARCH METHODS}

\subsection{Subjects}

Subjects of this study were amino acids in food and feed samples after being hydrolyzed by means of HPA-S.

\subsection{Equipment, tools and chemicals}

The high pressure asher (HPA-S) system was from Anton paar, with the ability to maintain the maximum temperature of $300^{\circ} \mathrm{C}$ and the maximum pressure of 130 bar. High-performance liquid

\footnotetext{
*Tel:0987980874_Email: chemvietchien@gmail.com
} 
chromatography system with fluorescent detector, and specific column for simultaneous analysis of 17 amino acids, C18 column normally for analysis of some essential amino acids was used in this study.

Pure chemicals meet the requirements for analysis, including was: $\mathrm{HCl} 37 \%, \mathrm{NaOH}$, and $\mathrm{Na}_{2} \mathrm{~B}_{4} \mathrm{O}_{7} \cdot 10 \mathrm{H}_{2} \mathrm{O}$ from Merck. Standard solutions of amino acids and single standards of amino acids: Lysine (Lys), Arginine (Arg), Threonine (Thr), Glutamic acid (Glu) were from Sigma. The ACCQ amino acid derivative kit was from Waters. Other chemicals used for analysis such as Ammonium acetate, Methanol from Merck, O-phthaldialhehyd (OPA) and 2-mercaptoethanol (2-MCE) from Sigma. Distilled water was used. Nitrogen has reached the level of $99.999 \%$ purity.

In addition, other laboratory instruments such as centrifuge tubes, volumetric flasks, filter paper, indicator paper and other common tools were used.

\section{RESULTS AND DISCUSSION}

\subsection{Survey conditions for analyzing four essential amino acids (Lys, Arg, Thr, Glu)}

To facilitate the evaluation of sample hydrolysis, due to the structure and similar chemical properties of amino acids, four essential amino acids including lysine, arginine, threonine, and glutamic acid were selected. Conditions for the separation and analysis of four amino acids simultaneously with $\mathrm{C} 18$ column using pre-column derivative with OPA reagents were surveyed with parameters that greatly affect the resolution, intensity and stability of analyte signal such as gradient mobile phase program and derivation time. The specific chromatographic conditions are described:

- C18 column (150 mm x $4.6 \mathrm{~mm} \times 3.5 \mu \mathrm{m})$;

- Mobile phase: A: $\mathrm{CH}_{3} \mathrm{COONH}_{4} 20 \mathrm{mM}$; B: Methanol, according to an appropriate gradient program to completely separate four amino acids.

- Flow rate: $0.5 \mathrm{~mL} / \mathrm{min}$

- Flourescence detector: $\lambda_{\mathrm{ex}}: 340 \mathrm{~nm} ; \lambda_{\mathrm{em}}: 455 \mathrm{~nm}$

- Injection: $20 \mu \mathrm{L}$

- Column temperature: $400^{\circ} \mathrm{C}$

- Derivation time: $60 \mathrm{~s}$

The chromatogram of four amino acid mixtures is shown in Figure 1.

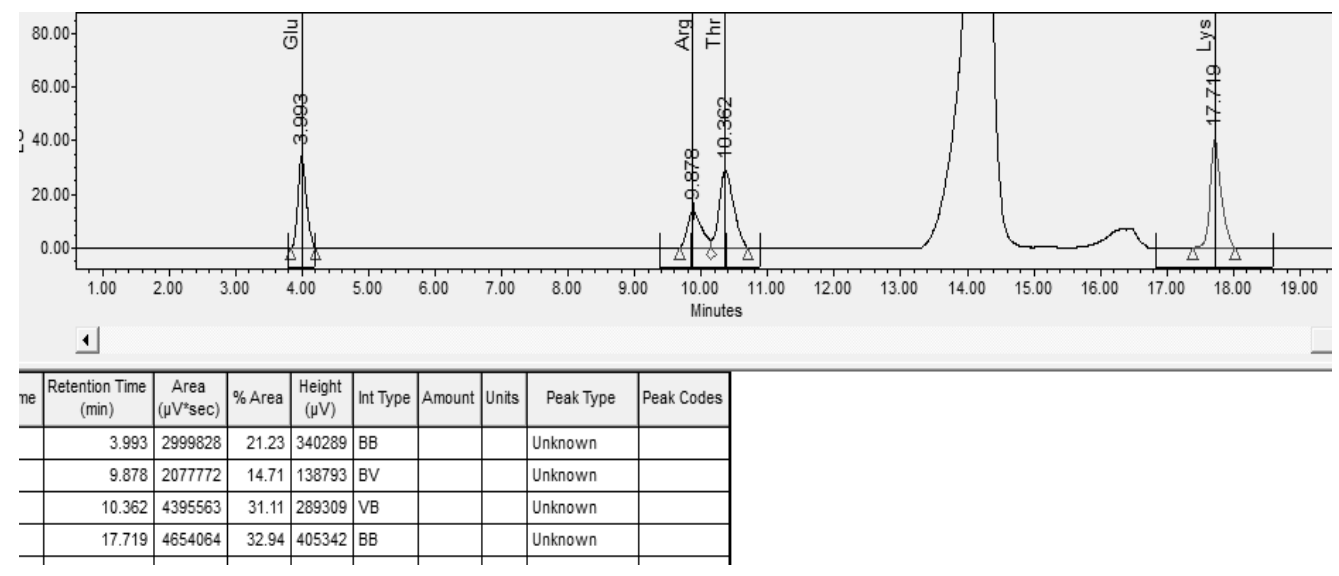

Figure 1. Chromatogram of four amino acid mixtures

The peak of four amino acids were separated well. The retention time was 20 minutes which suitable to investigate the hydrolysis of samples on HPA-S equipment.

\subsection{Survey of hydrolysis conditions with HPA-S}

\subsubsection{Survey of sample hydrolysis temperature program}

Temperature is the most important factor determining the efficiency of hydrolysis. To select the appropriate sample hydrolysis temperature, it is necessary to survey of representative food 
samples (powder milk) and animal feed (TACN - premix form), according to different temperature programs with sample weight $(0.5 \mathrm{~g})$, the volume of $\mathrm{HCl} 6 \mathrm{~N}$ acid $(5 \mathrm{~mL})$, and hydrolysis time is 45 minutes. The hydrolysis programs are summarized in Table 1.

Table 1. Program of hydrolysis temperature of amino acid samples

\begin{tabular}{|l|c|c|c|c|}
\hline \multirow{2}{*}{ Steps } & \multicolumn{4}{|c|}{ Temperature } \\
\cline { 2 - 5 } & Program 1 & Program 2 & Program 3 & Program 4 \\
\hline Step 1 & $80^{\circ} \mathrm{C}-5 \mathrm{~min}$ & $80^{\circ} \mathrm{C}-5 \mathrm{~min}$ & $80^{\circ} \mathrm{C}-5 \mathrm{~min}$ & $80^{\circ} \mathrm{C}-5 \mathrm{~min}$ \\
\hline Step 2 & $120^{\circ} \mathrm{C}-10 \mathrm{~min}$ & $120^{\circ} \mathrm{C}-10 \mathrm{~min}$ & $120^{\circ} \mathrm{C}-10 \mathrm{~min}$ & $120^{\circ} \mathrm{C}-10 \mathrm{~min}$ \\
\hline Step 3 & $160^{\circ} \mathrm{C}-10 \mathrm{~min}$ & $160^{\circ} \mathrm{C}-10 \mathrm{~min}$ & $160^{\circ} \mathrm{C}-10 \mathrm{~min}$ & $160^{\circ} \mathrm{C}-10 \mathrm{~min}$ \\
\hline Step 4 & $200^{\circ} \mathrm{C}-20 \mathrm{~min}$ & $240^{\circ} \mathrm{C}-20 \mathrm{~min}$ & $270^{\circ} \mathrm{C}-20 \mathrm{~min}$ & $300^{\circ} \mathrm{C}-20 \mathrm{~min}$ \\
\hline Step 5 & \multicolumn{5}{|l}{ Cool to temperature of at least $40^{\circ} \mathrm{C}$} \\
\hline
\end{tabular}

Results of the analysis of 4 essential amino acids with different hydrolysis temperature programs are presented in Figures 2 and 3.

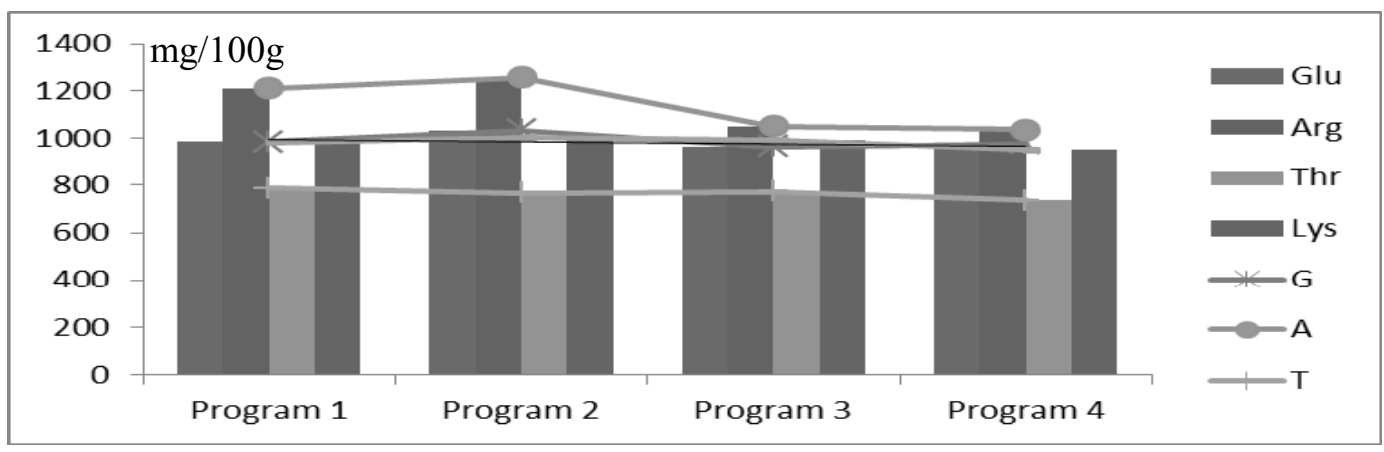

Figure 2. Results of hydrolysis survey of powder milk samples

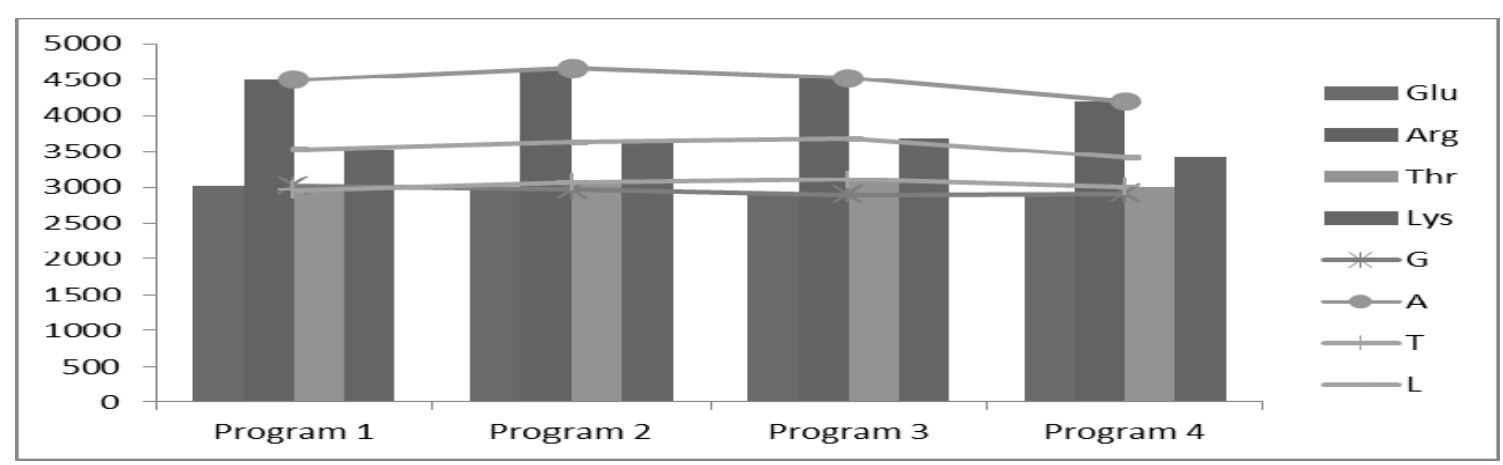

Figure 3. Results of hydrolysis survey of of feed samples

The hydrolysis process underwent various heating steps to react slowly. Accordingly, in program 2 corresponding to maximum temperature of $240^{\circ} \mathrm{C}$, amino acid content in the samples reached the highest and most stable values. However, there has not been so much change when increasing the temperature in the range of 200 to $300^{\circ} \mathrm{C}$ (the reduction of content at less $20 \%$ with $\mathrm{Arg}$ ). Therefore, the maximum hydrolysis temperature was selected at $240^{\circ} \mathrm{C}$ and remains fixed for the next survey steps.

\subsubsection{Survey of sample hydrolysis time}

The time of sample hydrolysis was investigated after the maximum sample hydrolysis temperature of $240^{\circ} \mathrm{C}$ was selected. Hydrolysis needs to be changed in the last step of the 46 | Vietnamese Journal of Food Control (No. 2-2019) 
temperature program before running the cooling process within about 10 - 30 minutes. The specific conditions are shown in Table 2.

Table 2. Survey of hydrolysis time of amino acid samples

\begin{tabular}{|l|c|c|c|c|}
\hline \multirow{2}{*}{ Steps } & \multicolumn{4}{|c|}{ Temperature } \\
\cline { 2 - 5 } & Program 1 & Program 2 & Program 3 & Program 4 \\
\hline Step 1 & $80^{\circ} \mathrm{C}-5 \mathrm{~min}$ & $80^{\circ} \mathrm{C}-5 \mathrm{~min}$ & $80^{\circ} \mathrm{C}-5 \mathrm{~min}$ & $80^{\circ} \mathrm{C}-5 \mathrm{~min}$ \\
\hline Step 2 & $120^{\circ} \mathrm{C}-10 \mathrm{~min}$ & $120^{\circ} \mathrm{C}-10 \mathrm{~min}$ & $120^{\circ} \mathrm{C}-10 \mathrm{~min}$ & $120^{\circ} \mathrm{C}-10 \mathrm{~min}$ \\
\hline Step 3 & $160^{\circ} \mathrm{C}-10 \mathrm{~min}$ & $160^{\circ} \mathrm{C}-10 \mathrm{~min}$ & $160^{\circ} \mathrm{C}-10 \mathrm{~min}$ & $160^{\circ} \mathrm{C}-10 \mathrm{~min}$ \\
\hline \multirow{2}{*}{ Step 4 } & $200^{\circ} \mathrm{C}-10 \mathrm{~min}$ & $240^{\circ} \mathrm{C}-15 \mathrm{~min}$ & $240^{\circ} \mathrm{C}-20 \mathrm{~min}$ & $240^{\circ} \mathrm{C}-30 \mathrm{~min}$ \\
& Total: 35 min & Total: $\mathbf{4 0}$ min & Total: $\mathbf{4 5}$ min & Total: 55 min \\
\hline Step 5 & Cool to temperature of at least $40^{\circ} \mathrm{C}$ \\
\hline
\end{tabular}

Results of analysis of 4 essential amino acids with different hydrolysis time programs are given in Figure 4 and Figure 5.

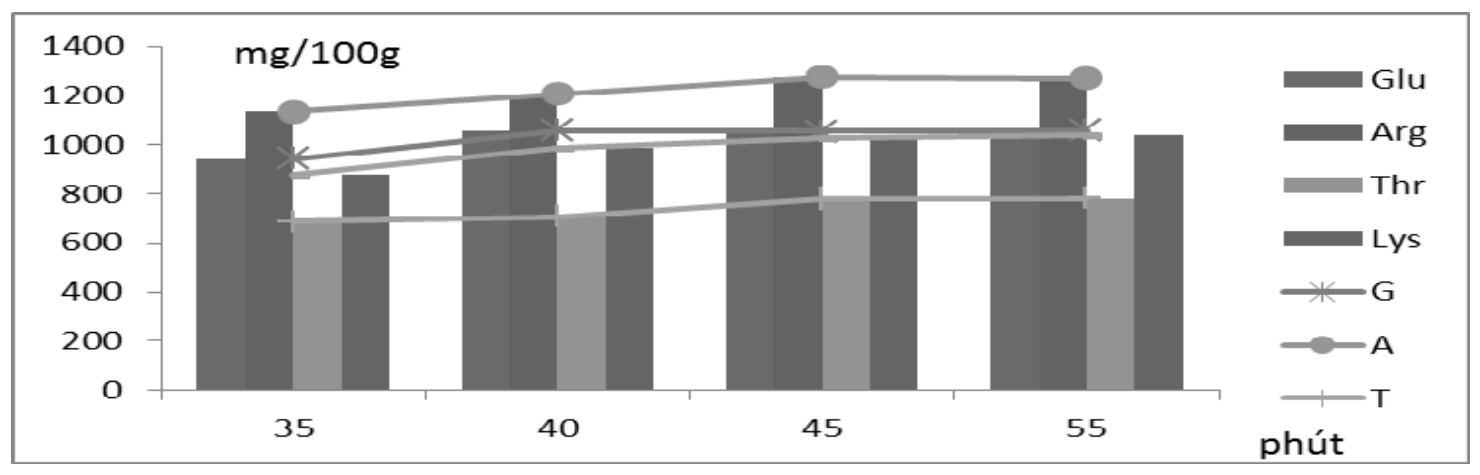

Figure 4. Survey results of hydrolysis time of powder milk samples

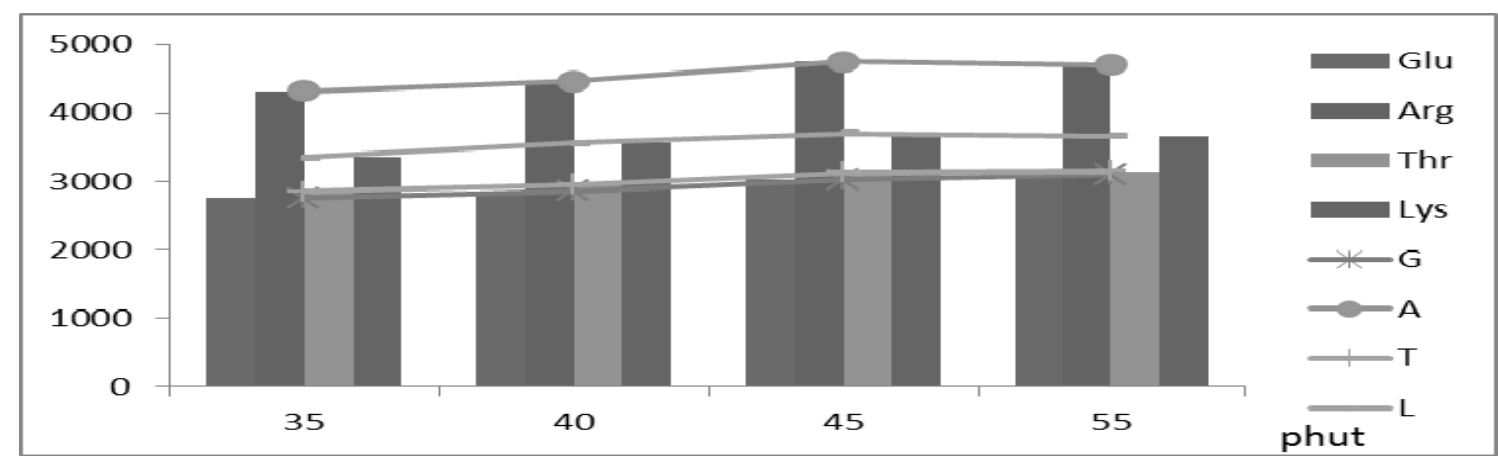

Figure 5. Survey results of hydrolysis time of feed samples

The results revealed that the amino acids content tended to rise when the hydrolysis time increases, and reached the maximum time at 45 minutes for hydrolysis process. After that, the amino acids content turned out to be stable, not significantly changed despite extended hydrolysis time. Therefore, the optimal sample hydrolysis time is selected as long as 45 minutes.

\subsubsection{Survey of sample weight}

Study on the hydrolysis response of HPA-S system was undertaken different sample weight in the range of 0.1 to $1.2 \mathrm{~g}$, with the conditions of time and hydrolysis temperature selected on a powder milk sample (20\% protein) and a feed sample (60\% protein). The results are given in Figure 6 and Figure 7. 


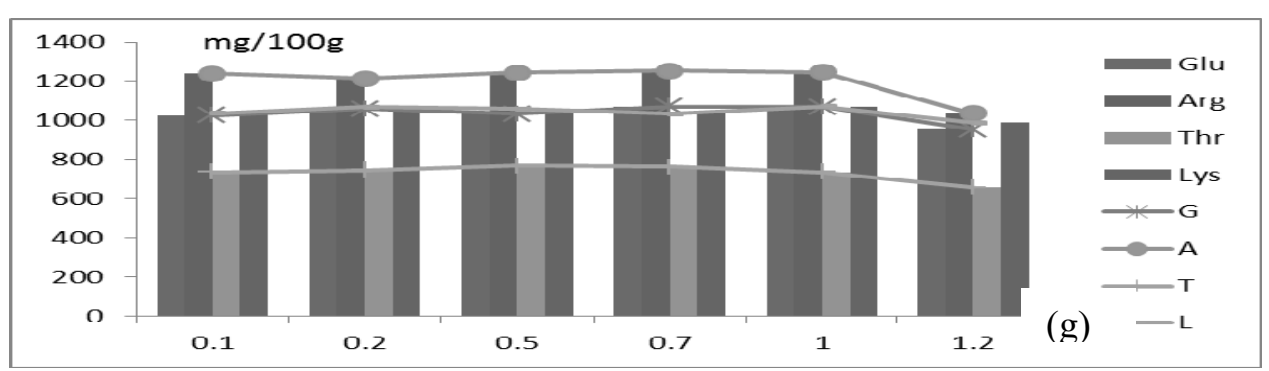

Figure 6. Correlation of amino acids content and milk samples mass

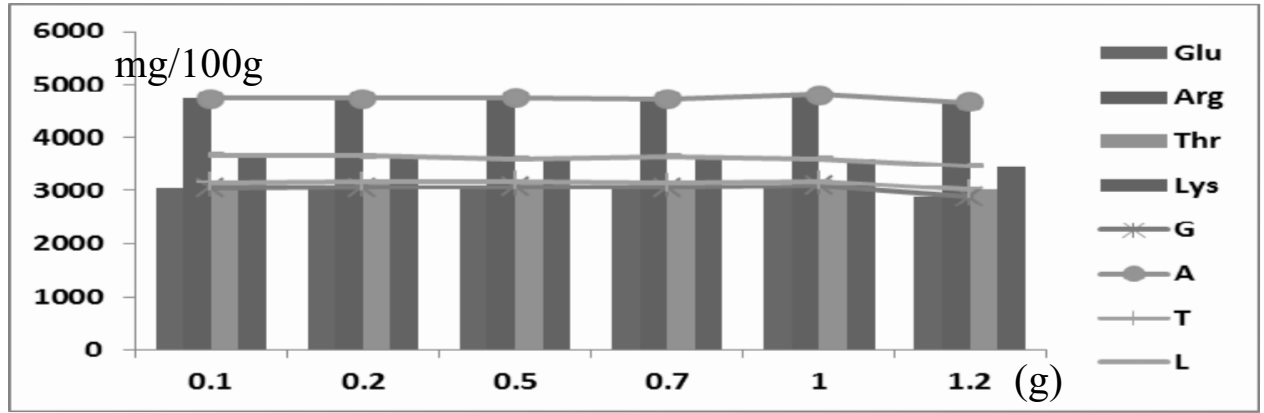

Figure 7. Correlation of amino acids content and feed samples mass

The survey results of the mass of hydrolyzate samples based on powder milk and feed samples with protein content of about $20-60 \%$ indicated that, when the weight of the sample increased gradually from 0.1 to $1 \mathrm{~g}$, the content of amino acids remained tend to be stable (results range within $\pm 5 \%$ ). However, with the weight of the sample of $1.2 \mathrm{~g}$, the amino acids content tended to decrease sharply (the highest decrease of 20\%). Therefore, the weight content of the samples should not exceed $1 \mathrm{~g}$, unless there is a further study of the concentration and amount of $\mathrm{HCl}$ acid using sample hydrolysis.

\subsection{Sample processing process}

Under the survey conditions, the procedure for determining amino acids after hydrolysis on HPA-S is summarized in Figure 8:

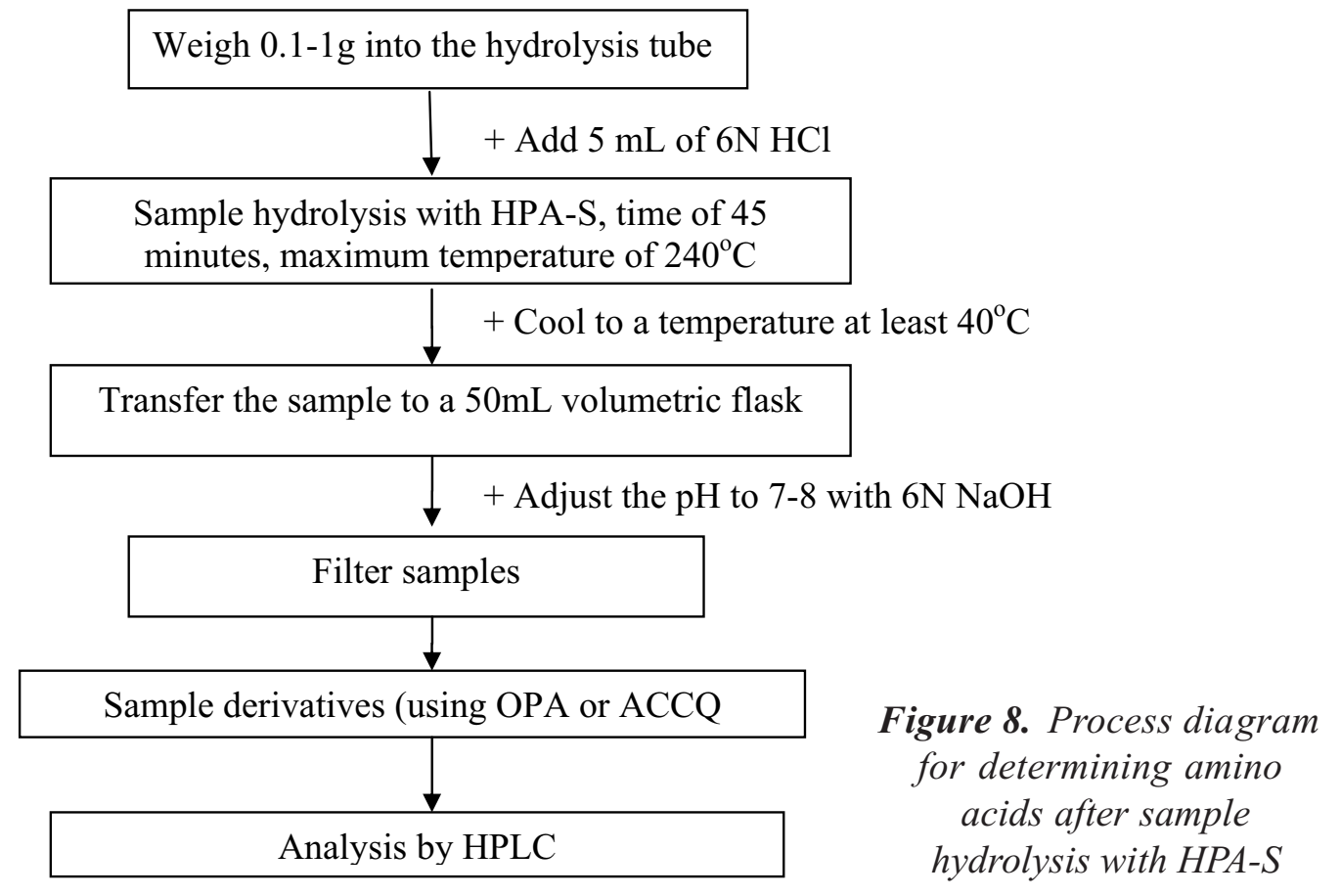


Comparision between two samples treatment process by using HPA-S and oven, due to the operating principle and structural characteristics of the HPA-S system, it is possible to increase the temperature to $240^{\circ} \mathrm{C}$ to completely break down protein peptide bonds within a short time (about 45 minutes). In addition, the hydrolysis system is completely sealed for better repeatability and stability.

\subsection{Evaluating hydrolysis process by using HPA-S and oven according to routine method at NIFC}

The results of amino acid analysis based on the hydrolysis process using HPA-S and oven currently applied according to the routine method at NIFC were evaluated. Several food and feeding samples were selected, simultaneously analyzed 17 amino acids according to the pre-column derivative process with ACCQ reagent, and analyzed four essential amino acids using derivatives OPA by HPLC, then each pair of experimental data by a paired t-test could be compared. The analytical results are summarized in Table 4 and Table 5.

Table 4. Results of evaluation of amino acid analysis samples using ACCQ derivatives

\begin{tabular}{|c|c|c|c|c|c|c|c|c|c|}
\hline \multirow{2}{*}{ Amino acids } & \multicolumn{3}{|c|}{$\begin{array}{l}\text { Pork meat } \\
(\mathrm{mg} / 100 \mathrm{~g})\end{array}$} & \multicolumn{3}{|c|}{$\begin{array}{c}\text { Powder milk } 1 \\
(\mathrm{mg} / \mathrm{l} 00 \mathrm{~g})\end{array}$} & \multicolumn{3}{|c|}{$\begin{array}{l}\text { Feeding } 1 \\
\text { (mg/100g) }\end{array}$} \\
\hline & HPA-S & Oven & $\mathrm{d}_{\mathrm{i}}(\%)$ & HPA-S & Oven & $\mathrm{d}_{\mathrm{i}}(\%)$ & HPA-S & Oven & $\mathrm{d}_{\mathrm{i}}(\%)$ \\
\hline $\begin{array}{l}\text { Glutamic } \\
\text { acid }\end{array}$ & 1,705 & 1,551 & 9.40 & 453 & 412 & 9.50 & 4,884 & 4,275 & 13.3 \\
\hline Arginine & 1,131 & 1,075 & 5.17 & 816 & 776 & 5.15 & 2,967 & 2,846 & 4.16 \\
\hline Threonine & 774 & 866 & 11.3 & 851 & 953 & 11.3 & 2,484 & 2,676 & 7.44 \\
\hline Lysine & 1,738 & 1,999 & 13.9 & 1,582 & 1,820 & 14.0 & 4,320 & 4,779 & 10.0 \\
\hline$T_{\text {cal }}$ & \multicolumn{3}{|c|}{3.15} & \multicolumn{3}{|c|}{2.26} & \multicolumn{3}{|c|}{3.02} \\
\hline $\begin{array}{c}T_{\text {theory }} \\
(P=0.95 ; \\
f=3)\end{array}$ & \multicolumn{3}{|c|}{3.18} & \multicolumn{3}{|c|}{3.18} & \multicolumn{3}{|c|}{3.18} \\
\hline
\end{tabular}

Table 5. Results of evaluation of amino acid analysis samples using OPA derivatives

\begin{tabular}{|c|c|c|c|c|c|c|c|c|c|}
\hline \multirow{2}{*}{ Amino acids } & \multicolumn{3}{|c|}{$\begin{array}{c}\text { Powder milk } 2 \\
(\mathrm{mg} / 100 \mathrm{~g})\end{array}$} & \multicolumn{3}{|c|}{$\begin{array}{c}\text { Functional food } \\
\text { (mg/100g) }\end{array}$} & \multicolumn{3}{|c|}{$\begin{array}{l}\text { Feeding } 2 \\
(\mathrm{mg} / \mathrm{l} 00 \mathrm{~g})\end{array}$} \\
\hline & HPA-S & Oven & $d_{i}(\%)$ & HPA-S & Oven & $d_{i}(\%)$ & HPA-S & Oven & $\mathrm{d}_{\mathrm{i}}(\%)$ \\
\hline Glutamic acid & 705 & 668 & 5.40 & 1,774 & 1,657 & 6.80 & 4,325 & 4,468 & 3.30 \\
\hline Arginine & 620 & 634 & 2.20 & 1,866 & 2,065 & 10.1 & 4,522 & 4,372 & 3.41 \\
\hline Threonine & 790 & 695 & 12.8 & 1,363 & 1,323 & 3.01 & 3,765 & 3,689 & 2.10 \\
\hline Lysine & 758 & 702 & 7.71 & 2,184 & 1,879 & 15.0 & 3,629 & 3,532 & 2.72 \\
\hline$T_{c a l}$ & \multicolumn{3}{|c|}{2.94} & \multicolumn{3}{|c|}{2.91} & \multicolumn{3}{|c|}{0.69} \\
\hline $\begin{array}{c}T_{\text {theory }} \\
(P=0.95 ; f=3)\end{array}$ & \multicolumn{3}{|c|}{3.18} & \multicolumn{3}{|c|}{3.18} & \multicolumn{3}{|c|}{3.18} \\
\hline
\end{tabular}

The analyzed results of food and feed samples in Table 4 and Table 5 all give the value of $\mathrm{T}_{\text {cal }}<\mathrm{T}_{\text {theory }}$, demonstrating that two methods of hydrolysis using oven and HPA-S with different sample backgrounds give similar results. Therefore, it may be concluded that the sample hydrolysis method with HPA-S can replace the sample hydrolysis method with an oven to determine the content of amino acids, to shorten sample preparation, but still ensures stability and high accuracy.

\section{CONCLUSIONS}

Evaluation the results of amino acids analysis on food and feed samples by two hydrolysis 
procedures (HPA-S and oven) showed quite similar results. However, the hydrolysis process using HPA-S shortens the sample preparation and provides higher stability.

The study has contributed to the proposal of a new method of treating amino acid analysis samples that can be applied at the NIFC. In addition, this study gives a chance to develop the application of sample preparation by HPA-S for analyzing other substances apart from metal elements.

\section{REFERENCES}

1. TCVN 8764:2012 Animal Feeds- Methods of determining amino acids content.

2. Le Thi Hong Hao, Pham Luan, Nguyen Xuan Trung (2006), "Application of high-performance liquid chromatography with column derivative using AQC regent to simultaneously isolate and identify 17 amino acids in fish", Journal of Chemistry, Physics and Biology, Volume 11, No. 2/2006, pages 15-23.

3. Ta Thi Thao (2010), Statistical syllabus in analytical chemistry, Faculty of Chemistry Viet Nam National University, Ha Noi.

4. Shi-Wen Sun, Yi-Cheng Lin, Yih-Ming Weng, Min-Jane Chen (2006), "Efficiency of improvement on nihydrin method for amino acids quantification", Journal of Food and analysis, 19, p112-117.

5. Jing-Joan Xu, Ying Peng, Ning Bao, Xing-Hua Xia, Hong-Yuan Chen (2005), "Simple method of the separation and detection of native amino acids and the identification of electroactive and non-electroactive analytes", Journal of Chromatography A, 1095, p-193-196.

6. Lourdes Bosch, Amparo Alegria, Rosaura Farre (2006), "Application of the 6-aminoquinolylN-hydroxysuccinimidyl carbamate (AQC) reagent to the RP-HPLC determination of amino acids in infant foods", Journal of Chromatography B, 831, p.176-183.

\section{Tóm tắt}

NGHIÊN CÚU QUY TRÌNH THỦY PHÂN MẪU THỬC PHẨM, THỨC ĂN CHĂN NUÔI BẰNG THIÊT BỊ TRO HÓA MÃ̃U ÁP SUÂT CAO (HPA-S) NHẰM XÁC ĐỊNH ĐỒNG THỜI HÀM LƯợNG MỘT SỐ ACID AMIN BẰNG HPLC

\section{Đinh Viết Chiến, Nguyễn Tiến Luyện, Nguyễn Thị Hồng Ngọc, Phạm Công Hiếu, Đỗ Tất Thành, Phạm Thu Giang, Tô Quốc Tường, Nguyê̂n Thị Lan, Dưong Minh Tuấn, Doãn Văn Kiên}

Viện kiểm nghiệm an toàn vệ sinh thực phẩm Quốc gia

Nghiên cứu này phát triển quy trình thủy phân mẫu thực phẩm và thức ăn chăn nuôi bằng thiết bị tro hóa mẫu áp suất cao (HPA-S) nhằm xác định một số acid amin bằng sắc ký lỏng hiệu năng cao (HPLC). Thiết bị HPA-S được sử dụng chủ yếu trong xử lý mẫu cho phân tích các kim loại bằng quang phổ. Tuy nhiên, nghiên cứu cũng cho thấy HPA-S có thể được sử dụng trong việc thủy phân các mẫu thực phẩm và thức ăn chăn nuôi nhằm mục đích phân tích các acid amin. Thiết bị HPA-S có thể đạt nhiệt độ tối đa tới $300^{\circ} \mathrm{C}$, và duy trì liên tục ở áp suất 130 bar, giúp phá hủy hoàn toàn những nền mẫu phức tạp nhất. Việc nghiên cứu thành công ứng dụng của thiết bị HPA-S để thủy phân mẫu phân tích các acid amin làm rút ngắn đáng kể thời gian của bước chuẩn bị mẫu, mà vẫn cho độ ổn định tương đương, thậm chí cao hơn các phương pháp thủy phân mẫu thông thường.

Tù̀ khóa: thục phẩm, thức ăn chăn nuôi, acid amin, HPA-S, thủy phân, HPLC. 